Fruit Crops

\title{
RESISTANCE TO STREPTOMYCIN BY BACTERIAL PATHOGENS OF STONE-FRUIT
}

\author{
J.M. YOUNG \\ Plant Diseases Division, DSIR, Auckland
}

Summary

Isolates of Pseudomonas syringae, resistant to high concentrations of streptomycin, have been obtained from apricot from orchards in Central Otago. Isolates of Xanthomonas pruni, tolerant to low concentrations of streptomycin have been obtained from nectarine from field trials in Havelock North and Auckland. The possible role of streptomycin resistant pathogens in disease outbreaks is discussed.

\section{INTRODUCTION}

Bacterial blast, caused by Pseudomonas syringae van Hall 1902 and bacterial spot, caused by Xantbomonas pruni (Smith 1903) Dowson 1939, are the most serious bacterial diseases of stone-fruits in New Zealand. Standard recommendations for control include spray applications of streptomycin from bud movement during the period that the pathogen is active.

Concern has been expressed that the effectiveness of streptomycin could be vitiated by the development of resistance in populations of the pathogens. A survey of possible resistance to streptomycin was conducted.

\section{METHOD}

Epiphyte populations of $P$. syringae from fifteen orchards of apricot in Central Otago showing blast, and of $X$. pruni from single 'spot' affected nectarine trial blocks in Havelock North and Auckland, were examined for resistance. Trees which had not been sprayed with streptomycin in the season, and trees which had been sprayed one or more times, were sampled.

Leaf samples were washed in flasks, and the washings plated onto separate media which encouraged distinctive colony forms of $P$. syringae and $X$. pruni. The media were prepared contining 0,10, 20, 50 and $100 \mathrm{ppm}$ streptomycin sulphate (745 international units streptomycin/ mg streptomycin sulphate) and colonies which developed at the $r:$, hest concentrations of streptomycin were subcultured for further testing. The identity of colonies as $P$. syringae and $X$. pruni was confirmed using a number of determinative tests.

Isolates of the pathogens were screened for resistance to streptomycin on a medium containing a range of concentrations $0-1000 \mathrm{ppm}$ streptomycin sulphate.

Resistant and susceptible isolates of $P$. syringae were inoculated into peach cv 'Golden Queen' to test the pathogenicity of the isolates. The methods above are described in detail elsewhere (Young 1977)

Proc. 30th N.Z. Weed and Pest Control Conf. 


\section{Fruit Crops}

The competitive ability of streptomycin resistant $P$. syringae isolates was tested against wild type (susceptible) isolates by coinoculating equal populations (one resistant isolate with one susceptible isolate) in broth culture. Counts of the total population and the resistant population were made by plating the broth culture onto nutrient agar and onto nutrient agar containing $100 \mathrm{ppm}$ streptomycin sulphate. At $24 \mathrm{~h}$ intervals the mixed population was sampled to determine any change in proportion of resistance to susceptible cells.

Doubling times of susceptible and resistant isolates were estimated by the method of Young et al (1977).

\section{RESULTS}

Large numbers of $P$. syringae and $X$. pruni susceptible to streptomycin were regularly isolated from apricot orchards and nectarine trial blocks, indicating the presence of populations of these pathogens in the trees which were surveyed.

a. P. syringae. From six orchards which had been sprayed with streptomycin at a rate of $100 \mathrm{ppm}, P$. syringae resistant to $1000 \mathrm{ppm}$ streptomycin was regularly isolated. Numbers of cells present varied considerably, but commonly exceeded 100 cells/leaf. In general, streptomycin resistant $P$. syringae was obtained from orchards where one or more streptomycin sprays had been applied. In one case, streptomycin resistant $P$. syringae was obtained from an orchard reported to have had no streptomycin sprays that season.

Pathogenicity tests showed that the proportion of pathogenic isolates in the resistant population was not significantly different from the proportion of pathogens in the population of wild type organisms.

Within $24 \mathrm{~h}$ of co-inoculation with the wild type isolates the proportion of streptomycin resistant organisms declined from $50 \%$ to $0.01 \%$. The mean doubling time of wild type $P$. syringae was $1.5 \mathrm{~h}$ and for the resistant organisms was $3.4 \mathrm{~h}$.

b. $\quad X$. pruni. Isolates of this pathogen resistant to $10 \mathrm{ppm}$ and 20 ppm streptomycin were occasionally obtained from the nectarines sprayed with $100 \mathrm{ppm}$ streptomycin. However, these were only capable of very slow growth compared with the wild type.

\section{DISCUSSION}

Resistance to streptomycin developed in populations of $P$. syringae. It has not been established whether resistance arises de novo in each season or whether a small resident resistant population survives from the previous season. Although the resistant organisms are pathogenic, their slow growth rate suggests that they are less likely than wild type pathogens to induce a serious disease outbreak unless there are prolonged conditions favourable for disease and unless sustained programmes of streptomycin are maintained.

$X$. pruni resistant to streptomycin was not obtained. Occasionally, isolates tolerant to concentrations lower than that used in recommended spray programmes were obtained, but these would not be expected to be effective in causing disease outbreaks. 


\section{Fruit Crops}

The small number of streptomycin sprays applied to stone-fruit do not appear to induce the high populations of virulent pathogens. resistant to streptomycin necessary to induce serious outbreaks of disease. Heavy spray protocols might lead to disease by resistant populations.

\section{REFERENCES}

Young, J.M., 1977. Resistance to streptomycin in Pseudomonas syringae from apricot. N.Z.Jl. Agric. Res.: 20 (in press).

Young, J.M., Luketina, R.C. and Marshall, A.M., 1977. The effects of temperature on growth in vitro of Pseudomonas syringae and Xantbomonas pruni. J. Appl. Bact.: 42 (in press). 